\title{
Influence of time of feeding on dam performance prepartum and postpartum and its impact on its kids
}

\author{
Moyosore Joseph Adegbeye ${ }^{1 *} \mathbb{C}$, Oluwatosin Bode Omotoso ${ }^{1}$, Adebowale Noah Fajemisin ${ }^{1}$, Samuel \\ Olanrewaju Aro ${ }^{1}$, Damilola Deborah Obadare ${ }^{1}$, Michael Eyitope Adunbi ${ }^{1}$ and Tolulope Oreoluwa Faniyi ${ }^{2}$
}

\begin{abstract}
Background: This study was conducted to evaluate the impact of time of feeding on the performance of WAD goats during pregnancy, and to assess how the time of feeding of the dam affect the growth of their kids' postpartum. Twelve (12) pregnant does were used in the pre-partum and in the postpartum, the same 12 lactating does and their 12 kids ( 1 kid per doe) were used. The dams were randomly distributed into three treatments and were fed once daily either in the morning, noon, or evening at $0600 \mathrm{~h}, 12: 00 \mathrm{~h}$ and 18:00 $\mathrm{h}$ respectively under the natural light-dark cycle.

Result: Serum creatinine in noon-fed does was higher $(P=0.005)$ than in morning and evening-fed does. In addition, low density lipoprotein in morning-fed gravid does was the high $(P=0.007)$ compared to noon-fed does while the evening-fed does had the lowest. During postpartum, morning and noon-fed dams consumed more feed (forage, concentrate, and total daily feed intake) than evening-fed dams $(P \leq 0.006)$. Kid weight of morning-fed does was numerically higher than noon-fed does, which was higher than kids of evening-fed does.
\end{abstract}

Conclusion: This study shows that time of feeding did not affect the performance of pregnant WAD goats. However, it has the potential to influence the serum parameters of pregnant animals. It also showed that time of feeding influences maternal feed intake postpartum and can influence the growth of the kids.

Keywords: Dam performance, Growth performance, Maternal nutrition, Pregnancy, Preweaning, Time of feeding

\section{Background}

Many physiological functions in the body exist in a circadian rhythm, which are under the control of the suprachiasmatic nucleus ( $\mathrm{SCN}$ ) located in the hypothalamus which serves as master clock and control clocks that exist in other visceral tissues known as peripheral clocks via hormonal, nutrient, and visceral cues (Adamovich et al. 2014; Challet 2019). The peripheral clocks in the body can be controlled by time of food consumption when time of feed intake is different from normal time of feeding leading to

\footnotetext{
*Correspondence: alanspeco@yahoo.com

${ }^{1}$ Department of Animal Production and Health, Federal University of Technology, Akure, Nigeria

Full list of author information is available at the end of the article
}

a desynchronization between the master clock and peripheral clocks (Damiola et al. 2000; Plaut and Casey 2011). This desynchrony can affect insulin sensitivity of body tissues, nutrient absorption and nutrient use in mammary and non-mammary tissues (Nikkhah et al. 2008; Pan and Hussain 2009; Niu and Harvatine 2018). The tendency of feed intake time to invert the expression of several physiological and productive rhythms imply that it could have impact on dam and fetus development. However, there are no studies on the influence of feeding time on pregnancy in goats. Studies in human-a diurnal mammal shows that circadian misalignment found to occurs in night shift workers causes alteration in physiological parameters such as hormone and sleep-wake cycles (Nehme 
et al. 2019) and the occurrence in pregnant humans, increased the risk of negative consequences such as abortion, low birthweight, and preterm birth (Whelan et al. 2007, Lawson et al. 2009, Fernandez et al. 2016). Performance of offspring has been linked with the rate of blood flow in dams between the uterus and placenta (Wu et al. 2006) with lower blood flow causing poor development (Lemley 2017). Manu et al. (2019) reported that pregnant sows fed daily ration at latter times of the day (11:30 $\mathrm{h}$ and 15:30 $\mathrm{h}$ ) had higher weight compared to those receiving it early $(07: 30 \mathrm{~h})$, but it did not affect birth weight. This suggest that time of nutrient delivery can affect nutrient flow to the placenta and mammary gland which can affect fetal growth and performance, udder development and lactational yield.

The undeniable relationship between nutrition and its impact on neonate development in mammals is established and the success of conception to parturition phase is influenced by many factors including nutrition and management strategies (Fontaine 2012; Spencer 2013). Prepartum and postpartum, the neonate depends exclusively on the dam for nutrient supply, colostrum, and milk till weaning or until they can take other solids apart from milk. Due to the impact of time of feeding as a potent zeitgeber for peripheral circadian clocks, altered feeding time would affect both mammary and non-mammary nutrient uptakes, and as a result, milk secretion and peripheral nutrient retention can be improved or reduced (Nikkhah 2011). Nikkhah et al. (2008) and Salfer and Harvatine (2020) have established that time of feeding affects milk yield and composition. Based on the above scenario, alteration of milk yield and composition may affect the preweaning performance of their kids. Preweaning performance of goat kids is important because the survival and weight gain of kids from birth to weaning impact lifetime productivity and profitability of goat industry (Akpa et al. 2010; Andries 2013). It is predominantly influenced by maternal milk production and can affect preweaning weight gain, weaning weight and future reproductive performances (Luginbul 2002; Snyman 2017; Sikiru and Makinde 2018). However, there is no study that has reported on the impact of time of feeding on gravid dams and blood metabolites, and preweaning performance of dams and kids. It is therefore novel to investigate the influence of the time of feeding on goat performance and blood metabolite during pregnancy. Also, we look to investigate how the time of feeding of a dam affect the growth of her kids.

\section{Methods}

Experimental site

All experiment phases were carried out at the Goat unit, Teaching and Research farm of the Federal University of Technology, Akure. The grass (Panicum maximum) was obtained from Federal University of Technology, Akure campus using cut and carry method. The experiment is grouped into two phases, the prepartum and post-partum phase.

\section{Performance of pregnant does during prepartum phase Experimental procedure}

Twelve primiparous does were used for the experiment and grouped into three treatments of four replicates and weighed prior to mating. The does used for mating are 36 months old. The does were synchronized by natural method with virile bucks to stimulate ovulation and served two times after signs of heat. The does were housed individually with free access to water and feed diet (Table 1). The does were fed once daily at either 06:00 $\mathrm{h}, 12: 00 \mathrm{~h}$ and 18:00 h, respectively under the natural light-dark cycle. Feeding trail for each animal started 21 days after the initial mating when the animals did not return to heat, and they were observed for another 21 days after the feeding trail had started. In total, the experiment from mating to parturition occurred between December 2019 to May 2020. The performance of the does during pregnancy were evaluated by calculating the daily feed intake as the difference between feed offered and leftover weight. The weight of the gravid does was taken weekly and used to calculate the total pregnancy accretion and average daily pregnancy accretion. On the day of parturition, the birth weight, the number of kid(s), and the postpartum dam weight were taken.

Table 1 Chemical composition of experimental diet (g/100 g)

\begin{tabular}{lcc}
\hline Parameters & Concentrate & Grass \\
\hline Dry matter & 86.96 & $27.91^{*}$ \\
Crude protein & 10.70 & 7.81 \\
Crude fibre & 15.73 & 32.55 \\
Ether extract & 3.46 & 3.39 \\
Ash & 13.82 & 12.50 \\
Acid detergent lignin & 16.12 & 19.99 \\
Acid detergent fibre & 30.07 & 26.55 \\
Neutral detergent fibre & 72.03 & 63.94 \\
Hemicellulose & 41.96 & 37.39 \\
Cellulose & 13.95 & 6.55 \\
Nitrogen free extract & 56.30 & 43.75 \\
\hline
\end{tabular}

*Dry matter of fresh grass 


\section{Serum and haematology}

Blood samples were collected from the gravid does $24 \mathrm{~h}$ post-feeding at the fifth month of parturition respectively via the jugular vein puncture using hypodermic syringes into Vacutainer tubes (Becton Dickinson, Franklin Lakes, NJ, USA). Blood sampling from each animal was performed at the same hour of the day when each group of animals were fed by veterinarians to minimize stress. Ten $(10 \mathrm{ml})$ of blood samples were collected with $2 \mathrm{ml}$ in ethylenediaminetetraacetic acid bottles and $8 \mathrm{ml}$ in non-ethylenediaminetetraacetic acid bottle for hematological and serum biochemical assay respectively. Haematological parameters such as packed cell volume, white blood cell, white blood cell different counts, red blood cell, erythrocyte sedimentation rate and haemoglobin were carried out according to Dacie and Lewis (2001). The red blood cell, haemoglobin, and packed cell volume values were used to calculate the mean corpuscular haemoglobin concentration, mean corpuscular haemoglobin, and mean corpuscular volume using appropriate formulae by Dacie and Lewis (2001). Albumin, globulin and total protein was determined using the colorimetric bromocresol green method of Clinichem reagent kit Budafoki street, Budapest, aspartate aminotransferase, and alanine aminotransferase were carried out with the method provided by Sigma-Aldrich ${ }^{\circledR}$ assay kit, serum parameters such as glucose, urea, creatinine, alkaline phosphatase, triglyceride, cholesterol, lipoproteins (HDL and LDL) were determined using a commercial test kit (Randox Laboratories Ltd., Crumlin, Co. Antrim, UK) and finally measured using a UV Spectrophotometer (SEAC, Florence, Italy). The ambient temperature and relative humidity were measured by digital hygro-thermometer (Thermopro TP50). The temperature humidity index was determined from the recorded daily relative humidity and ambient temperature according to Marai et al. (2001);

$$
\mathrm{THI}=\mathrm{db}^{\circ} \mathrm{C}-\left\{(0.31-0.31 \mathrm{RH})\left(\mathrm{db}{ }^{\circ} \mathrm{C}-14.4\right)\right\}
$$

where $\mathrm{THI}=$ Temperature-humidity index, $\mathrm{db}^{\circ} \mathrm{C}=$ Dry bulb temperature ${ }^{\circ} \mathrm{C} . \mathrm{RH}=$ Relative humidity $(\mathrm{RH} \%) / 100$.

THI was rated as follows: ahs=absence of heat stress (values $<22.2$ ), mhs $=$ moderate heat stress (values between 22.2 and $<23.3$ ), shs $=$ severe heat stress (values between 23.3 and $<25.6$ ), ehs $=$ extreme heat stress (values from 25.6 and more).

\section{Performance of does during postpartum phase Does, feeding and experimental design}

The post-partum experiment lasted for 6 weeks with twelve pregnant WAD does and their twelve kids. Each doe gave birth to one kid. The does were on their first parity and they were maintained in the same treatment from the prepartum phase. All kids were kept with
Table 2 Gross composition (g/100 g) of the concentrate

\begin{tabular}{lc}
\hline Ingredient & Diet \\
\hline Cassava peel & 40.00 \\
Palm kernel cake & 26.00 \\
Wheat offals & 14.00 \\
Brewer dried grains & 15.00 \\
Bone meal & 2.00 \\
Urea & 1.00 \\
Premix & 1.00 \\
Salt & 1.00 \\
\hline
\end{tabular}

their dam except during milk yield intake record. Furthermore, the dams were housed individually, had free access to feed which was grass (Panicum maximum) and concentrate (Table 2) in 50:50 dry matter ratio. The goat-does were fed once daily in the morning, noon, or evening at $06: 00 \mathrm{~h}, 12: 00 \mathrm{~h}$ or 18:00 $\mathrm{h}$ respectively under the natural light-dark cycle.

\section{Kids performance during postpartum}

At birth the initial weight was taken, and afterwards the kids were weighed weekly, and the weight was used to calculate the weight gain, average daily gain, and the kid final weight. The average daily weight gain was calculated after estimation of weaning weight. All kids were allowed to stay one week with their mother postpartum to build intimacy with their dam and to allow enough time for colostrum intake. All days of the weeks the kids remained with their dam, except on days when milk offtake record was to be taken. Average daily gain was calculated as the total weight gain divided by the number of days between birth and weaning. The postpartum lasted for 6 weeks.

\section{Milk offtake record of kids}

The milk yield was measured by an indirect method using the weigh-suckle-weigh method (Williams et al. 1979). Prior to taking milk intake records, the kids of all dams were withdrawn at 18:00 $\mathrm{h}$ the previous day irrespective of the feeding time of their dam. The milk intake records were taken three time in week and five times per day. The kids suckled their dam five times a day at 06:05 h, 09:00 h, 12:05 h, 15:00 h, and 18:05 h and were withdrawn 15 mins later for weighing. Dams that did not allow their kids to suckle were restricted to permit suckling. This milk offtake data was collected for five weeks starting from the 2nd, 3rd, 4th, 5th, and 6th week postpartum and the average milk intake was calculated. 
Table 3 Performance of WAD gravid does during pregnancy

\begin{tabular}{|c|c|c|c|c|c|}
\hline Parameters & Morning & Noon & Evening & SEM & $P$ value \\
\hline Initial weight (kg) & 11.64 & 12.01 & 10.88 & 0.451 & 0.627 \\
\hline Final weight (kg) & 20.6 & 19.25 & 20.22 & 0.562 & 0.641 \\
\hline Average daily gain (g) & 74.71 & 60.38 & 77.77 & 4.567 & 0.273 \\
\hline Total weight gain (kg) & 8.97 & 7.25 & 9.33 & 0.554 & 0.273 \\
\hline Daily feed intake (g) & 462.08 & 444.43 & 422.64 & 20.471 & 0.77 \\
\hline Total feed intake (kg) & 55.12 & 52.89 & 50.30 & 2.462 & 0.762 \\
\hline Feed conversion ratio & 6.13 & 7.56 & 5.53 & 0.413 & 0.105 \\
\hline Daily forage intake (g) & 85.11 & 84.13 & 76.53 & 3.518 & 0.596 \\
\hline Total forage intake (kg) & 10.13 & 10.01 & 9.11 & 0.428 & 0.596 \\
\hline Daily concentrate intake (g) & 376.97 & 360.3 & 346.11 & 17.863 & 0.812 \\
\hline Total concentrate intake (kg) & 44.86 & 42.86 & 41.19 & 2.129 & 0.812 \\
\hline Gestation period (days) & 142.75 & 143.75 & 141.24 & 0.839 & 0.509 \\
\hline Number of offspring & 1.00 & 1.00 & 1.00 & 0.000 & - \\
\hline Dam weight postpartum (kg) & 18.90 & 18.25 & 18.70 & 0.511 & 0.889 \\
\hline Weight of kids at birth (g) & 1327.25 & 1209.00 & 1398.50 & 175.45 & 0.999 \\
\hline
\end{tabular}

\section{Chemical and mineral analysis}

The proximate of feed samples was analyzed for Ash (method ID 942.05), N from Kjeldahl method (method ID 954.01), Ether extract (method ID 920.39) according to (AOAC 1997). The Neutral detergent fibre (NDF), acid detergent fibre (ADF), and acid detergent lignin (ADL) were analyzed according to (Van Soest et al. 1991). Hemicelluloses was calculated as NDF-ADF while cellulose was calculated as ADF-ADL.

\section{Data analysis}

For the dam record during prepartum and postpartum, and kids completely randomized design was used. All data collected were subjected to analysis of variance (ANOVA) using SPSS version 23.0 (SPSS 2015). The differences between treatment means were examined by Duncan multiple range test of the same package.

\section{Result}

Performance and blood profile of gravid does

Feeding WAD does once daily in the morning, noon or evening did not affect $(P>0.05)$ feed intake, growth performance, and haematology of pregnant WAD goats (Tables 3, 4). Notwithstanding, the total weight gained during gestation showed that the does fed in the evening had highest weight while those fed at noon had the lowest weight. The average gestation period in this study (141143 days) is lower than the average 150 days expected of goats. Serum creatinine in noon-fed gravid does was higher $(P=0.005)$ than in morning and evening-fed does.

Table 4 Haematological parameter of Gravid WAD does during pregnancy

\begin{tabular}{|c|c|c|c|c|c|}
\hline Parameters & Morning & Noon & Evening & SEM & $P$ value \\
\hline Erythrocyte sedimentation rate $(\mathrm{mm} / \mathrm{h})$ & 0.50 & 0.50 & 0.50 & - & - \\
\hline Packed cell volume (\%) & 28.67 & 26.67 & 28.33 & 0.510 & 0.256 \\
\hline Red blood cell $\left(\times 10^{6} / \mathrm{mm}^{3}\right)$ & 11.83 & 10.75 & 11.65 & 0.302 & 0.315 \\
\hline White blood cell $\left(\times 50 / \mathrm{mm}^{3}\right)$ & 282.00 & 261.00 & 277.33 & 6.201 & 0.399 \\
\hline Haemoglobin $\left(\times 10^{6} / \mathrm{mm}^{3}\right)$ & 9.57 & 8.87 & 9.47 & 0.181 & 0.234 \\
\hline Mean corpuscular haemoglobin (pg) & 8.08 & 8.29 & 8.12 & 0.110 & 0.763 \\
\hline Mean corpuscular volume (fl) & 24.22 & 24.94 & 24.3 & 0.342 & 0.697 \\
\hline Mean corpuscular haemoglobin concentration (\%) & 33.37 & 33.25 & 33.41 & 0.031 & 0.065 \\
\hline Lymphocyte (\%) & 59.33 & 60.33 & 59.67 & 0.432 & 0.694 \\
\hline Neutrophils (\%) & 28.00 & 28.00 & 27.67 & 0.517 & 0.959 \\
\hline Monocytes (\%) & 8.00 & 8.00 & 7.67 & 0.269 & 0.87 \\
\hline Eosinophils (\%) & 4.00 & 3.33 & 4.33 & 0.261 & 0.317 \\
\hline Basophils (\%) & 0.67 & 0.67 & 0.67 & 0.174 & 1.000 \\
\hline
\end{tabular}


The serum low density lipoprotein decreases as the time of feeding moved from dawn to dusk. The does fed in the morning had the highest $(P=0.007)$ low density lipoprotein while the evening-fed does had lowest. The environmental parameters showed that during the experimental period, the ambient temperature of the morning was the lowest $(P<0.001)$, followed by the evening temperature while the highest temperature was recorded at noon. In contrast, result of the relative humidity showed that morning period had the highest value $(P<0.001)$ followed by the evening period while the afternoon had the lowest. The temperature humidity index showed that morning feeding time had the lowest $(P<0.001)$ while noon feeding time had the highest (Table 5).

\section{Feed intake of lactating WAD does and preweaning performance of WAD kids}

Table 6 shows the feed intake and growth performance of WAD does. The result shows that feeding in the morning and noon enhanced $(P \leq 0.002)$ daily feed intake and daily forage intake than evening feeding (Table 6). The does fed in the evening had the lowest feed intake while those fed in the morning and noon had similar feed intake. Furthermore, lactating WAD does fed in the morning had the highest $(P=0.006)$ concentrate intake while those fed in the evening had the lowest. Noon-fed lactating does had the highest forage intake while those fed in the evening had the lowest forage intake. Kids born to dams fed in the morning consumed $(P<0.001)$ more milk than kids of dams fed at noon and evening. Kids born to morning-fed dams had numerically higher weight postpartum than other treatments. However, time of feeding of dams had no impact $(P>0.05)$ on average daily gain and total gain at weaning.

\section{Discussion}

\section{Performance and blood profile of gravid does}

Gestation period is very important in reproductive performance of animal. The gestation period of goats in our study was lower than the average of 144.9 days reported by (Akusu and Ajala 2000). This may be associated with the variation in the treatment between studies or the variation in diet used. Nonetheless, the lowest days of gestation in the evening-fed does may be associated with the time of feeding. Report from Whelan et al. (2007) and Lawson et al. (2009) in pregnant diurnal mammals showed that there is a possibility of early birth. This could be the reason for the shortest gestation period in evening-fed goats. Serum physiological parameters are non-invasive method to assess the health of an animal (Jimoh et al. 2019). Blood urea nitrogen and creatinine are the final product of protein metabolism, and they are often regarded as indicator of renal functions (Song et al. 2020). Furthermore, in heat stressed animals, plasma

Table 5 Serum parameter of Gravid WAD does during pregnancy under different feeding time

\begin{tabular}{|c|c|c|c|c|c|}
\hline Parameters & Morning & Noon & Evening & SEM & $P$ value \\
\hline \multicolumn{6}{|l|}{ Serum parameters (mg/dl) } \\
\hline Glucose & 36.67 & 49.49 & 52.05 & 3.441 & 0.142 \\
\hline Protein & 60.70 & 40.67 & 41.44 & 4.332 & 0.079 \\
\hline Albumin & 11.64 & 11.94 & 11.62 & 0.191 & 0.789 \\
\hline Globulin & 49.06 & 28.73 & 29.83 & 4.447 & 0.090 \\
\hline Creatinine & $36.29^{b}$ & $94.86^{\mathrm{a}}$ & $36.93^{b}$ & 10.640 & 0.005 \\
\hline Urea & 42.04 & 14.48 & 27.66 & 5.079 & 0.057 \\
\hline \multicolumn{6}{|l|}{ Lipid profile (mg/dl) } \\
\hline Triglycerides & 23.80 & 21.69 & 28.92 & 2.042 & 0.381 \\
\hline Cholesterol & 114.55 & 79.79 & 122.87 & 9.478 & 0.136 \\
\hline High density lipoprotein & 94.13 & 82.23 & 120.63 & 15.157 & 0.635 \\
\hline Low density lipoprotein & $57.20^{\mathrm{a}}$ & $27.88^{b}$ & $7.10^{c}$ & 13.041 & 0.007 \\
\hline \multicolumn{6}{|l|}{ Liver function (U/L) } \\
\hline Alanine aminotransaminase & 7.40 & 7.73 & 7.47 & 0.758 & 0.986 \\
\hline Aspartate aminotransaminase & 18.50 & 21.00 & 22.33 & 1.952 & 0.771 \\
\hline Alkaline phosphatase & 110.4 & 115.00 & 111.32 & 10.343 & 0.989 \\
\hline \multicolumn{6}{|l|}{ Environmental parameters } \\
\hline Ambient temperature $\left(0^{C}\right)$ & $24.99^{c}$ & $31.93^{\mathrm{a}}$ & $30.60^{b}$ & 0.415 & $<0.001$ \\
\hline Relative humidity (\%) & $91.63^{\mathrm{a}}$ & $65.83^{b}$ & $66.25^{b}$ & 1.649 & $<0.001$ \\
\hline Temperature humidity index & $24.72^{c}$ & $30.02^{\mathrm{a}}$ & $28.88^{b}$ & 0.319 & $<0.001$ \\
\hline
\end{tabular}

abc: means with superscript are significant $(P<0.05)$ 
Table 6 Feed intake (g DM/d) of WAD does postpartum and pre-weaning performance of WAD kids

\begin{tabular}{|c|c|c|c|c|c|}
\hline Parameters & Morning & Noon & Evening & SEM & $P$ value \\
\hline \multicolumn{6}{|l|}{ Feed intake } \\
\hline Forage intake & $303.70^{\mathrm{a}}$ & $325.39^{\mathrm{a}}$ & $262.82^{b}$ & 7.234 & $<0.001$ \\
\hline Concentrate intake & $429.68^{\mathrm{a}}$ & $385.36^{\mathrm{ab}}$ & $346.36^{b}$ & 10.074 & 0.006 \\
\hline Daily feed intake & $724.04^{\mathrm{a}}$ & $716.87^{\mathrm{a}}$ & $610.06^{b}$ & 14.864 & 0.002 \\
\hline \multicolumn{6}{|l|}{ Kid performance } \\
\hline Birth weight (g) & 1327.25 & 1209.00 & 1398.50 & 175.453 & 0.999 \\
\hline Kid final weight (g) & 4208.75 & 3726.25 & 3726.25 & 144.31 & 0.293 \\
\hline Weight gain (g) & 2881.5 & 2517.25 & 2327.75 & 167.72 & 0.431 \\
\hline Average daily gain (g) & 72.12 & 60.38 & 58.50 & 4.051 & 0.363 \\
\hline Milk intake of kids (g/day) & $411.10^{\mathrm{a}}$ & $312.68^{b}$ & $355.82^{\mathrm{b}}$ & 10.206 & $<0.001$ \\
\hline
\end{tabular}

abc: mean with superscript are significant $(P<0.05)$

cholesterol was reported to decrease while creatinine increased (Abeni et al. 2007; Baumgard and Rhoads 2013; Van laer et al. 2015). Plasma creatinine-an indicator of skeletal muscle breakdown-can increase in the blood serum due to heat stress (Abeni et al. 2007). The temperature humidity index in this study showed that all goats were heat stressed. The general heat stress in all goats can be attributed to the well-known high ambient temperature in the tropics. However, the highest index from the afternoon feeding time showed that the does fed at noon experienced more heat stress. This may be due to the coincidence of high ambient temperature with metabolic heat production due to feeding period. This heat stress was further confirmed by the increased serum creatinine in noon-fed gestating does. Thus, the higher heat stress in noon-fed pregnant goats may be the reason for the increase in blood creatinine compared to morning and evening-fed does. Although not reported in pregnant goat, dyslipidemia have been reported to occur in pregnant and non-pregnant humans who eat at "wrong time" of the day, resulting in elevated blood cholesterol, triglycerides, LDL cholesterol, and lower HDL cholesterol, and could increase pre-term birth risk (Bailey et al. 2014; Jiang et al. 2017; Reinke and Asher 2019). In our study, LDL in noon-fed does was lower than morning-fed does while evening-fed goats had the lowest LDL. The reason for this contrasting result in LDL profile is not known at this time. However, Leibowitz (1988) reported on the preference of animals for protein and fat as nutrient at the expense of carbohydrate when fed at the inactive phase/wrong time, because melatonin secretion which is higher at night reduces glucose uptake from the blood (Van Cauter et al. 1998; Qaid and Abdelrahman 2016) in diurnal mammals. Thus, the increasing demand for nutrients by the fetus, and lower glucose uptake in eveningfed animals due to insulin insensitivity at night might have caused the mobilization of cholesterol as alternative form of energy resulting in lower availability of LDLcholesterol in evening-fed does compared to other feeding time. Overall, the serum parameters in our study are similar to Jimoh et al. (2019) for late gestating WAD does.

\section{Feed intake of WAD does and preweaning performance of WAD Kids}

During postpartum higher daily forage and concentrate intake in morning and noon-fed does compared to evening-fed does in our study contradicts the report of Nikkhah et al. (2006, 2008) who reported that feed intake in the evening-fed cows was higher than morning-fed dairy cows. This variation may be attributed to the light unavailability in our study after evening feeding which reduced their intake. In these studies (Nikkhah et al. 2006, 2008), illumination was provided for $3 \mathrm{~h}$ post-feeding in the dairy cow fed in the evening compared to our study where there was not light post-feeding.

Preweaning performance is an important parameter because it could affect the survival and weight gain, and impact the lifetime productivity and profitability of livestock industry. Since the offspring depends on the dam for their nutrient intake, the maternal nutrition of a dam could affect the growth and skeletal muscle development in livestock species during pre-weaning phase of their development. In this study, the average weight of kids born to morning-fed does was higher than kids born to noon and evening-fed does. The increased weight and weight gain of the kids that belong to morning-fed does is not surprising as they took more milk. Nonetheless, the weight at birth of this study is within the range reported by Oseni et al. (2017) and Oderinwale et al. (2020) for WAD kids. Furthermore, average daily gain in this study is within the range reported by Ayizanga et al. (2018) and Oderinwale et al. (2020). This suggests that the time of maternal nutrient intake could affect kids performance. 


\section{Conclusions}

In this study, we found that time of feeding did not affect the feed intake, growth performance and haematology of gravid WAD does. However, feeding time affected the serum parameters such as decrease in low density lipoprotein as feeding shifted from dawn to dusk and increased serum creatinine in gestating does fed at noon. Furthermore, during the postpartum phase, time of feeding influenced the feed intake of lactating does with a decrease in total intake as feeding shifted from dawn to dusk. Also, the choice of intake (forage or concentrate) was influenced by feeding time as morning-fed lactating does had the highest concentrate intake while noon-fed does had the highest forage intake. Similarly, kid weight and daily gain of morningfed does was similar but numerically higher compared to other feeding time. It was observed that irrespective of the time of feeding all goats were still heat stressed though the noon-fed gestating does were the most stressed while the morning-fed gestating does were least stressed.

Thus, based on this study, we conclude that time of feeding has influence on serum parameters during gestation, affects maternal feed intake postpartum and this impact on maternal nutrient intake could influence kids preweaning performance.

\section{Abbreviations \\ WAD: West African Dwarf; SCN: Suprachiasmatic nucleus; HDL: High density lipoprotein; LDL: Low density lipoprotein; RH: Relative humidity; ADG: Average daily gain; ADF: Acid detergent fibre; ADL: Acid detergent lignin; NDF: Neutral detergent fibre.}

\section{Acknowledgements}

The authors acknowledge the staff of Federal University of Technology, Akure Farm, and the Technologists in the laboratory of the Department of Animal Production and Health, and Biochemistry Department of Federal University of Technology Akure. We also thank the anonymous reviewers for their suggestions in improving this manuscript.

\section{Authors' contributions}

MJA, ANF, and SOA, conceived and designed the experiment; MJA, DDO, and MEA conducted the experiment; ANF, SOA, and OBO performed supervision; MJA and TOF prepared the manuscript. All authors read and approved the final manuscript.

\section{Funding}

Not applicable.

\section{Availability of data and materials}

It is available from the corresponding author on reasonable request.

\section{Declarations}

Ethics approval and consent to participate Not applicable.

\section{Consent for publication}

Not applicable.

\section{Competing interests}

The authors declare no competing interests.

\section{Author details}

${ }^{1}$ Department of Animal Production and Health, Federal University of Technology, Akure, Nigeria. ${ }^{2}$ Department of Crop and Animal Science, Faculty of Agriculture, Ajayi Crowther, Oyo, Oyo State, Nigeria.

Received: 14 October 2021 Accepted: 12 November 2021

Published online: 27 November 2021

\section{References}

Abeni F, Calamari L, Stefanini L (2007) Metabolic conditions of lactating Friesian cows during the hot season in the Po valley. 1. Blood indicators of heat stress. Int J Biomet 52:87-96

Adamovich Y, Rousso-Noori L, Zwighaft Z, Neufeld-Cohen A, Golik M, KrautCohen J, Wang M, Han X, Asher G (2014) Circadian clocks and feeding time regulate the oscillations and levels of hepatic triglycerides. Cell Metabol 19:319-330

Akpa GN, Alphonsus C, Dalha SY, Garba Y (2010) Goat breeding structure and repeatability of litter size in smallholder goat herds in Kano, Nigeria. Anim Res Int 7:1274-1280

Akusu MO, Ajala OO (2000) Reproduction performance of west African dwarf goats in the humid tropical environment of Ibadan. Israel J Vet Med $55: 1-9$

Andries KM (2013) Growth and performance of meat goat kids from two seasons of birth in Kentucky. Sheep Goat Res J 28:16-20

AOAC (1997) Official methods of analysis, 16th edn. Association of Official Analytical Chemists, Washington, DC

Ayizanga RA, Tecku PKM, Obese FW (2018) Growth and reproductive performance of West African dwarf goats at the Animal Research Institute, Katamanso Station. Ghana J Agric Sci 52:43-53

Bailey SM, Udoh US, Young ME (2014) Circadian regulation of metabolism. J Endocrin 222:R75-R96

Baumgard LH, Rhoads RP (2013) Effects of heat stress on postabsorptive metabolism and energetics. Annu Rev Anim Biosci 1:311-337

Challet E (2019) The circadian regulation of food intake. Nat Rev Endocrin 15:393-405

Dacie JV, Lewis SM (2001) Practical haematology, 9th edn. Churchill Livingstone, London

Damiola F, Le Minh N, Preitner N, Kornmann B, Fleury-Olela F, Schibler U (2000) Restricted feeding uncouples circadian oscillators in peripheral tissues from the central pacemaker in the suprachiasmatic nucleus. Genes Dev 14:2950-2961

Fernandez RC, Marino JL, Varcoe TJ, Davis S, Moran LJ, Rumbold AR, Brown HM, Whitrow MJ, Davies MJ, Moore VM (2016) Fixed or rotating night shift work undertaken by women: implications for fertility and miscarriage. Seminal Reprod Med 34:74-82

Fontaine E (2012) Food intake and nutrition during pregnancy, lactation and weaning in the dam and offspring. Reprod Dom Anim 47:326-330

Jiang S, Jiang J, Xu H, Wang S, Liu Z, Li M, Liu H, Zheng S, Wang L, Fei Y, Li X, Ding X, Wang Z, Yu Y (2017) Maternal dyslipidemia during pregnancy may increase the risk of preterm birth: a meta-analysis. Taiwan J Obste Gynecol 56:9-15

Jimoh AO, Ojo OA, Ihejirika UD (2019) Metabolic and oxidative status of West African dwarf does at different reproductive stages in southwest Nigeria. Bull Nat Res Centre 43:190-198

Lawson CC, Whelan EA, Hibert EN, Grajewski B, Spiegelman D, Rich-Edwards JW (2009) Occupational factors and risk of preterm birth in nurses. Am J Obstet Gynecol 200:51.e1-51.e8

Leibowitz SF (1988) Hypothalamic paraventricular nucleus:interaction between alpha 2-noradrenergic system and circulating hormones and nutrients in relation to energy balance. Neurosci Biobehav Rev 12:101-109

Lemley CO (2017) Investigating reproductive organ blood flow and blood perfusion to ensure healthy offspring. Anim Front 7:18-24. https://doi. org/10.2527/af.2017-0124 
Luginbul JM (2002) Monitoring the body condition of meat goats: a key to successful management Publication of the Extention Animal Husbandry, Department of Animal Science, NCSU

Manu H, Lee SH, Ren P, Pangeni D, Yang X, Baidoo SK (2019) Effects of time of feeding during gestation on sow's performance. J Anim Sci 97:1234-1241

Marai IFM, Ayyat MS, Abd El-Monem UM (2001) Growth performance and reproductive traits at first parity of New Zealand White female rabbits as affected by heat stress and its alleviation, under Egyptian conditions. Trop Anim Health Prod 33:457-462

Nehme PA, Amaral FG, Middleton B, Lowden A, Marqueze E, França-Junior I, Antunes JLF, Cipolla-Neto J, Skene DJ, Moreno CR (2019) Melatonin profiles during the third trimester of pregnancy and health status in the offspring among day and night workers: a case series. Neurobiol Sleep Circadian Rhy 6:70-76

Nikkhah A (2011) Timing of feed presentation entrains periprandial rhythms of energy metabolism indicators in once-daily fed lactating cows. Biol Rhy Res 43:1-14

Nikkhah A, Plaizier JC, Furedi CJ, Kennedy AD (2006) Response in diurnal variation of circulating blood metabolites to nocturnal vs diurnal provision of fresh feed in lactating cows. J Anim Sci 84(Suppl 1):111-118

Nikkhah A, Furedi CJ, Kennedy AD, Crow GH, Plaizier JC (2008) Effects of feed delivery time on feed intake, milk production, and blood metabolites of dairy cows. J Dairy Sci 91:4249-4260

Niu M, Harvatine KJ (2018) The effects of morning compared with evening feed delivery in lactating dairy cows during the summer. J Dairy Sci 101:396-400. https://doi.org/10.3168/jds.2017-13635

Oderinwale OA, Oluwatosin BO, Onagbesan MO, Akinsoyinu AO, Amosu SD (2020) Performance of kids produced by three breeds of goat fed diets supplemented with graded levels of turmeric powder. Trop Anim Health Prod 52:1239-1248

Oseni SO, Yakubu A, Aworetan AR (2017) Nigerian West African Dwarf goats. In: Simoes J, Guttierrez C (eds) Sustainable goat production in adverse environment. Springer, Berlin, pp 91-110

Pan X, Hussain MM (2009) Clock is important for food and circadian regulation of macronutrient absorption in mice. J Lipid Res 50:1800-1813

Plaut K, Casey T (2011) Does the circadian system regulate lactation? Animal 6:394-402. https://doi.org/10.1017/S1751731111002187

Qaid MM, Abdelrahman MM (2016) Role of insulin and other related hormones in energy metabolism-a review. Cogent Food Agric 2:1267691. https://doi.org/10.1080/23311932.2016.1267691

Reinke H, Asher G (2019) Crosstalk between metabolism and circadian clocks. Nat Rev Molec Cell Biol 20:227-241

Salfer IJ, Harvatine KJ (2020) Night-restricted feeding of dairy cows modifies daily rhythms of feed intake, milk synthesis and plasma metabolites compared to day-restricted feeding. Brit J Nutr. https://doi.org/10.1017/ S0007114520000057

Sikiru AB, Makinde OJ (2018) Effect of low-cost supplemental feeding practices on pre-weaning weight gain of goat kids in Tafa LGA Nigeria. Int J Agric Res Sust Food Suff 5:237-247

Snyman MA (2017) Growth rate of Angora goat kids from birth to 16 months of age. http://gadi.agric.za/articles/Snyman_MA/angora_groei.php

Song Y, Loor JJ, Zhao C, Huang D, Du X, Li X, Wang Z, Liu G, Li X (2020) Potential hemi-biological identification marker to the left displaced abomasum in dairy cows. BMC Vet Res 16:470-479

Spencer TE (2013) Early pregnancy: concepts, challenges, and potential solutions. Anim Front 3:48-55. https://doi.org/10.2527/af.2013-0033

SPSS (2015) IBM SPSS scientist statistics for windows, Version 230 USA. IBM SPSS Corp, Armonk

Van Cauter E, Moreno-Reyes R, Akseki EL, Hermite-Balériaux M, Hirschfeld U, Leproult R, Copinschi G (1998) Rapid phase advance of the $24 \mathrm{hr}$ melatonin profile in response to afternoon dark exposure. Am J Physiol Endocrin Metab 275:E48-E54

Van laer E, Tuyttens AM, Ampe B, Sonck B, Moons CPH, Vandaele L (2015) Effect of summer conditions and shade on the production and metabolism of Holstein dairy cows on pasture in temperate climate. Animal 9:1-12

Van Soest PJ, Robertson JB, Lewis BA (1991) Method of dietary fiber, neutral detergent fiber and non-starch polysaccharides in relation to animal nutrition. J Dairy Sci 74:3583-3597

Whelan EA, Lawson CC, Grajewski B, Hibert EN, Spiegelman D, Rich-Edwards JW (2007) Work schedule during pregnancy and spontaneous abortion. Epidemiology 18:350-355
Williams JH, Anderson DC, Kress DD (1979) Milk production in Hereford cattle. 1. Effects of separation interval on weigh-suckle-weigh milk production estimates. J Anim Sci 49:1438-1442

Wu G, Bazer FW, Wallace JM, Spencer TE (2006) Board-invited review: intrauterine growth retardation: implications for the animal sciences. J Anim Sci 84:2316-2337

\section{Publisher's Note}

Springer Nature remains neutral with regard to jurisdictional claims in published maps and institutional affiliations.

\section{Submit your manuscript to a SpringerOpen ${ }^{\circ}$ journal and benefit from:}

- Convenient online submission

- Rigorous peer review

- Open access: articles freely available online

- High visibility within the field

- Retaining the copyright to your article

Submit your next manuscript at $\boldsymbol{\nabla}$ springeropen.com 